\title{
Alpha-1 protease inhibitor and antichymotrypsin levels in acute pancreatitis
}

\author{
Akut pankreatitte alfa-1 proteaz inhibitorü ve antikimotripsin düzeyleri
}

\author{
Tamer KARŞIDAĞ, ${ }^{1}$ Sefa TÜZÜN, ${ }^{1}$ Ahu Sarbay KEMIK,${ }^{2}$ Sevim PURİSA, ${ }^{3}$ Aytekin ÜNLÜ ${ }^{4}$
}

\section{BACKGROUND}

Acute pancreatitis with high mortality of severe onset is still a major problem in medicine. Early identification of the severity of the disease is critical for effective treatment. Many markers have been tried and are still being tested. The ideal marker should be able to identify the cases and distinguish between mild and severe.

\section{METHODS}

This prospective study included 34 cases (14 males, 20 females, mean age: 58 years) of acute pancreatitis and 33 cases (17 males, 16 females, mean age: 53 years) as a control group. Mild $(n=29)$ and severe $(n=5)$ cases were compared with respect to serum levels of amylase, C-reactive protein (CRP), alpha-1-protease inhibitor, and antichymotrypsin on admission and 24 and 48 hours (h) after admission.

\section{RESULTS}

Alpha-1 protease inhibitor and antichymotrypsin levels were significantly elevated in the first $24 \mathrm{~h}$; however, CRP peaked after $48 \mathrm{~h}$ in the acute pancreatitis group. While CRP showed significantly higher concentrations in patients with severe pancreatitis, alpha-1-protease inhibitor and antichymotrypsin levels changed slightly, but without significance, in severe cases.

\section{CONCLUSION}

Alpha-1 protease inhibitor and antichymotrypsin are early events in acute pancreatitis, with high levels on admission. Activation of these variables declines after $24 \mathrm{~h}$. These markers may have early diagnostic value in patients with acute pancreatitis. Because neither of them is good at discrimination of mild and severe cases in the disease, they should not be incorporated into routine clinical investigations.

Key Words: Alpha-1 protease inhibitor; antichymotrypsin; acute pancreatitis.

\begin{abstract}
$A M A C ̧$
Şiddetli formundaki yüksek mortalite oranı ile akut pankreatit günümüzde halen tıbbın önemli bir sorunudur. Hastalığın şiddetinin erken belirlenmesi etkin tedavi için kritik öneme sahiptir. Çeşitli biyokimyasal belirteçler denenmiştir ve halen denenmektedir. İdeal belirteç olguyu tanıyabilmeli ve pankreatitin hafif ve şiddetli formlarını ayırt edebilmelidir.
\end{abstract}

\section{GEREÇ VE YÖNTEM}

Bu prospektif çalışmaya akut pankreatitli 34 olgu (14 erkek, 20 kadın, ort. yaş: 58 yaş) ve kontrol grubundaki 33 olgu (17 erkek, 16 kadın, ort. yaş: 53 yaş) dahil edildi. Hafif $(n=29)$ ve ağır $(n=5)$ olgular başvuru anındaki, başvurudan 24 ve 48 saat sonraki amilaz, C-reaktif protein (CRP), alfa-1 proteaz inhibitörü ve antikimotripsin düzeyleri aç1sından karşılaştırıldı.

\section{BULGULAR}

Akut pankreatit grubunda alfa-1 proteaz inhibitörü ve antikimotripsinin serum düzeyleri ilk 24 saatte yükseldi, buna karşın CRP 48 saat sonra pik değere ulaştı. CRP şiddetli pankreatitli hastalarda anlamlı derecede yüksek konsantrasyonlar gösterirken, alfa-1 proteaz inhibitörü ve antikimotripsin düzeylerindeki hafif değişimler anlamlı değildi.

\section{SONUÇ}

Başvuru anında yüksek düzeyleri ile alfa-1 proteaz inhibitörü ve antikimotripsin akut pankreatitte erken sonuçlar verir. Bu değişkenlerin aktivasyonları 24 saat sonra düşer. $\mathrm{Bu}$ belirteçlerin akut pankreatitli hastalarda erken tanı değeri olabilir. Her ikisi de bu hastalığın hafif ve şiddetli olgularını ayırmada iyi olmadığından, rutin klinik kullanıma dahil edilmemelidir.

Anahtar Sözcükler: Alfa-1 proteaz inhibitor; antikimotripsin; akut pankreatit.

\footnotetext{
12nd Department of Surgery, Haseki Training and Research Hospital,

Istanbul; ${ }^{2}$ Department of Biochemistry, IU Istanbul Faculty of Medicine, Istanbul; ${ }^{3}$ Department of Biostatistics, IU Cerrahpasa Faculty of Medicine, Istanbul; ${ }^{4}$ Division of Health, Gendermerie General Headquarters, Ankara, Turkey.
}
${ }^{1}$ Haseki Eğitim ve Araștırma Hastanesi, 2. Cerrahi Kliniği, İstanbul;
2̇.Ü., İstanbul Tıp Fakültesi, Biyokimya Anabilim Dalı, İstanbul;
${ }^{3}$ İ.Ü. Cerrahpaşa Tıp Fakültesi, Biyoistatistik Anabilim Dalı, İstanbul; ${ }^{4}$ Jandarma Genel Komutanlığı, Sağlık Komutanlığı, Ankara.


Necrotizing pancreatitis was first described by Nikolaus Tulp, a Dutch physician and anatomist, in 1652. ${ }^{[1]}$ All the descriptions of pancreatitis reflected severe onset of the disease, until 1929, when Elman, a surgical resident working under Professor Evarts Graham, reported the value of blood amylase in acute pancreatitis. ${ }^{[2]}$ After his report, identification and prediction of severe cases emerged as the next problem. Scoring systems such as Ranson, Imrie, Glasgow, and the Acute Physiology and Chronic Health Evaluation (APACHE II) are used for prediction of disease severity, but these scoring systems require up to 48 hours (h). In 1992, the Atlanta Classification on Pancreatitis was announced. Identification of mild and severe cases of the disease was universally accepted. ${ }^{[3]}$ Currently, there is no ideal marker to make this identification early, easy and fast.

Interleukin (IL)-6, tumor necrosis factor (TNF)- $\alpha$, C-reactive protein (CRP), and procalcitonin are wellknown markers, and have high sensitivity and specificity for early prediction. ${ }^{[4]}$ Medical researchers have also studied some rare markers. Alpha-1 protease inhibitor and antichymotrypsin are promising newly introduced tests in clinical practice; however, controversial results have been reported in the literature.

It has been suggested that proteolytic enzymes such as trypsin and elastase play a dominant role in the pathogenesis of acute pancreatitis. ${ }^{[5]}$ The potentially destructive effects of pancreatic enzymes on the pancreas itself are controlled by a number of protease inhibitors (such as alpha-1 protease inhibitor and antichymotrypsin) present in normal plasma. ${ }^{[6]}$ Alpha-1 protease inhibitor is also referred to as alpha-1 antitrypsin.

The aim of the present study was to establish whether alpha-1 protease inhibitor and antichymotrypsin were useful in the investigation for the diagnosis of acute pancreatitis and assessment of the disease severity. The validity of the enzymes as a marker for inflammation of the pancreatitis was compared with the amylase value, CRP and the diagnosis of the disease according to the Atlanta Classification.

\section{MATERIALS AND METHODS}

This prospective study included 34 cases of acute pancreatitis and 33 cases as the control group. Patients were classified according to their clinical outcome into two groups: mild pancreatitis and severe pancreatitis. Mild $(n=29)$ and severe $(n=5)$ cases were compared with respect to serum levels of amylase, CRP, alpha-1 protease inhibitor, and antichymotrypsin on admission and 24 and $48 \mathrm{~h}$ after admission. In mild cases, no lifethreatening complications were seen, whereas patients with severe disease manifested respiratory insufficiency, sepsis, shock, and renal failure. Death occurred in one of five patients with severe pancreatitis because of multiorgan failure. The control group was constituted by the patients who admitted for non-pancreatic abdominal pain and without inflammatory process.

Antichymotrypsin in serum was determined using particle-enhanced turbidimetric immunoassay method with commercially available specific antibodies (PETIA; Dako, Glostrup, Denmark). Alpha-1 protease inhibitor in serum was determined by nephelometry protein analyzer method (Technicon reagents, Tarrytown, NY, USA).

The enzymes were compared among groups using the Mann-Whitney $U$ test. The relation between mild and severe groups was compared by means of the $\mathrm{McNemar}$ test. Statistical analyses were performed using the Statistical Package for the Social Sciences for Windows (SPSS Inc., Chicago, IL, USA).

\section{RESULTS}

A total of 34 patients (14 males, 20 females, mean age: 58 years) were included in the study. Among the patients with acute pancreatitis and those with nonpancreatic abdominal pain, there were no significant differences in age $(\mathrm{p}=0.129)$ or $\operatorname{sex}(\mathrm{p}=0.326)$.

Thirty-three patients (17 males, 16 females, mean age: 53 years) who admitted for non-pancreatic abdominal pain and without inflammatory process were accepted as the control group.

During the course of the disease, 29 (85\%) patients had no complications, while $5(15 \%)$ patients developed local or systemic complications. According to the Atlanta criteria, the first group was classified as mild pancreatitis and the latter group as severe pancreatitis. Severe acute pancreatitis was defined as associated with organ failure and/or local complications, such as necrosis, abscess, or pseudocyst. In the severe group, pseudocyst was seen in two patients, renal failure with creatinine elevation in one patient and pulmonary insufficiency $\left(\mathrm{PaO}_{2}<60 \mathrm{mmHg}\right)$ in another. One patient (83 years old) with severe pancreatitis died on the third day of hospitalization because of multiorgan failure.

As compared with extra pancreatic controls, patients with acute pancreatitis had significantly higher values of amylase, CRP, alpha-1 protease inhibitor, and antichymotrypsin levels in serum on admission $(\mathrm{p}<0.001)$ (Table 1, Fig. 1).

All patients with acute pancreatitis had serum amylase values above at least 20 -fold the upper reference limit (40 U/L). Serum levels of CRP were above the upper reference limit in 20 patients $(74 \%)$ and serum amylase in 34 patients $(100 \%)$. Alpha-1 protease inhibitor and antichymotrypsin values were above about 
Table 1. Mean, minimum and maximum levels in the pancreatitis and control groups on admission and significance of the difference

\begin{tabular}{lllc}
\hline & Acute pancreatitis $(\mathrm{n}=34)$ & Control group $(\mathrm{n}=33)$ & $\mathrm{p}$ \\
\hline Serum amylase $(\mathrm{U} / \mathrm{L})$ & $2756(815-6887)$ & $30.42(16-44)$ & $<0.001$ \\
CRP $(\mathrm{mg} / \mathrm{L})$ & $36.19(0.5-236)$ & $2.91(1-5)$ & $<0.001$ \\
$\alpha 1$-protease inhibitor $(\mathrm{mg} / \mathrm{dl})$ & $22.09(15-30)$ & $10.15(4-15)$ & $<0.001$ \\
Antichymotrypsin $(\mathrm{mg} / \mathrm{dl})$ & $44.71(11-110)$ & $4.79(2-9)$ & $<0.001$ \\
\hline
\end{tabular}

two-fold and four-fold the upper reference limits (13 $\mathrm{mg} / \mathrm{dl}$ and $10 \mathrm{mg} / \mathrm{dl}$, respectively).

The relation of changes in serum levels of CRP, alpha-1 protease and antichymotrypsin to time and severity are shown in Figures 2 and 3, respectively.

Serum CRP values peaked within the third day,

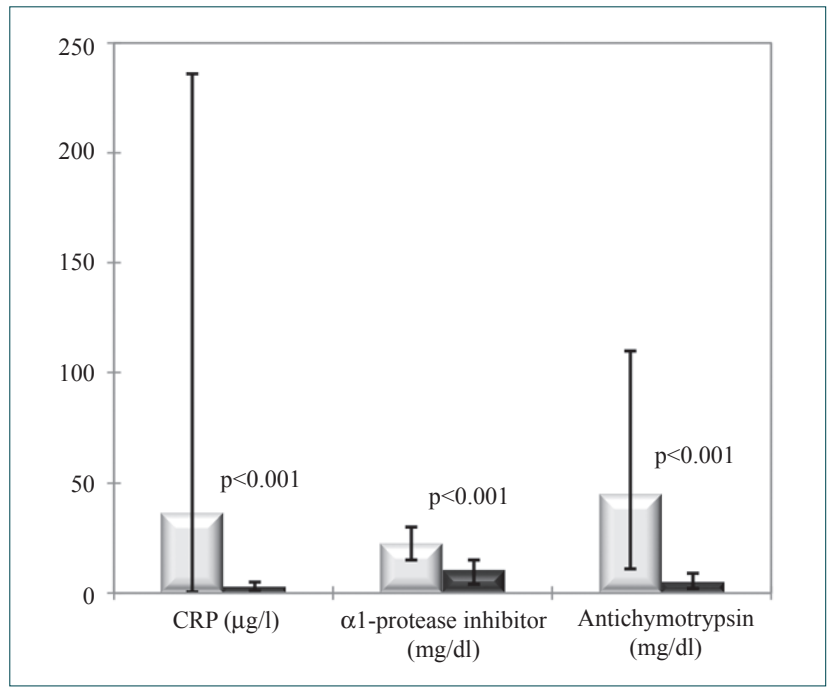

Fig. 1. Mean, minimum and maximum levels of CRP in pancreatitis (light bar) and control (dark bar) groups on admission, with significance of difference.

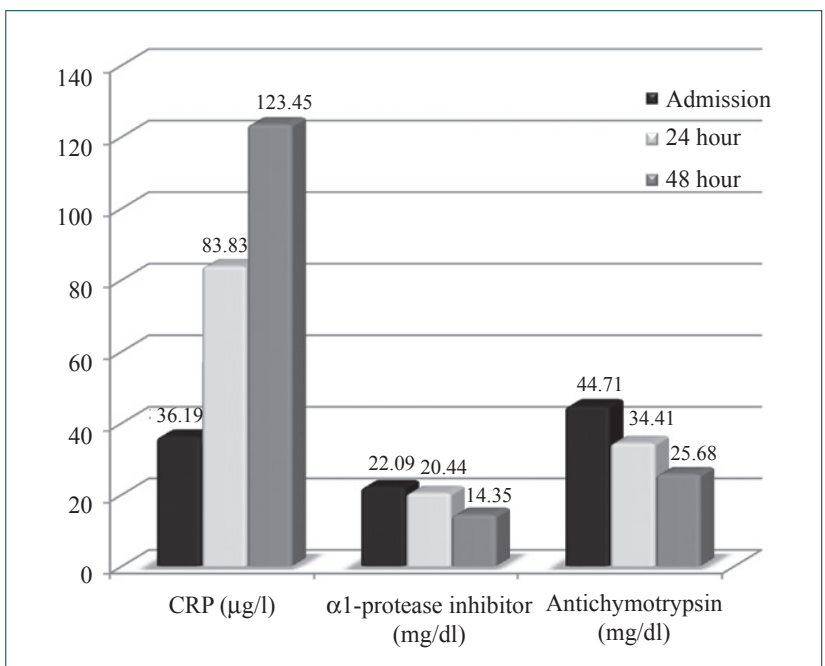

Fig. 2. Mean values in pancreatitis on admission and at 24 and 48 hours. with values considerably higher in the severe pancreatitis group. Serum alpha-1 protease inhibitor and antichymotrypsin values were also in high concentrations on the day of admission, and they decreased periodically without significant difference between mild and severe cases.

\section{DISCUSSION}

Early diagnosis and prediction of severity are the main targets for improved management of patients with acute pancreatitis. New developments in diagnostic imaging procedures, invasive percutaneous aspiration techniques and a variety of biochemical variables are under investigation to correlate with the development of major complications and severity of acute pancreatitis. ${ }^{[7-10]}$ Need for an ideal marker, which should be simple in test performance, accurate, available under emergency conditions, and cost-effective, is continuing. The usefulness of most markers in the clinic is limited. As an acute phase reactant, CRP is still in use as an ideal biochemical marker, with some disadvantages like late onset for prediction of severity. ${ }^{[11,12]}$

In this prospective clinical trial, alpha-1 protease inhibitor and antichymotrypsin were analyzed for diagnostic value and investigated for prediction of severity in patients with acute pancreatitis.

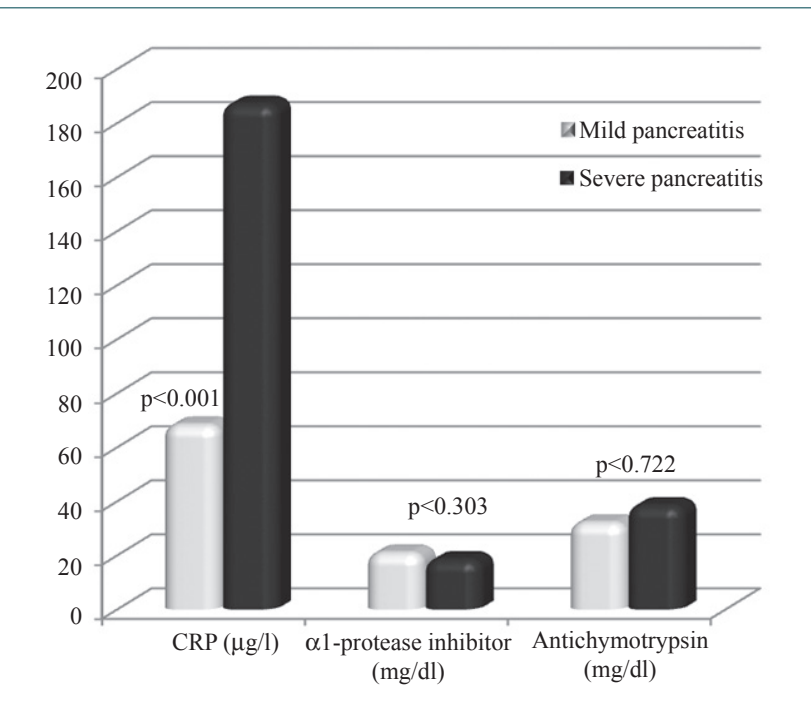

Fig. 3. Mean values in mild (light bar) and severe (dark bar) pancreatitis at 24 hours and significance of difference. 
This study has shown that alpha-1 protease inhibitor and antichymotrypsin levels increased rapidly in the first hours of the disease, before CRP increased. It is of advantage compared with CRP, especially in diseases with lower inflammatory reaction. This is the most important point of these markers for earlier assessment in clinical laboratories. These findings are compatible with those in the literature. ${ }^{[13-17]}$ Plasma values of CRP, alpha-1 proteinase inhibitor, alpha-2 macroglobulin, and complexed alpha-2 macroglobulin were determined in serial samples from 27 patients with acute pancreatitis by Banks et al. ${ }^{[13]}$ and were reported in 1991. Alpha-1 proteinase inhibitor was raised in both groups (mild and severe). Goodman et al. ${ }^{[14]}$ reported that serum levels of alpha-1 protease inhibitor and antichymotrypsin elevated significantly $(p<0.001)$ from day 0 in mild pancreatitis. They also reported these acute phase proteins become similarly elevated in severe cases, but the rapid rise in levels of alpha-1 protease inhibitor and antichymotrypsin from day 0 in mild pancreatitis seems to be delayed in severe disease. However, they did not mention about the significance of the difference. Hedstorm et al. ${ }^{[15]}$ studied trypsin-alpha-1 protease inhibitor complex. They found it increased in acute pancreatitis. McMahon and Lasson et al. ${ }^{[16,17]}$ reported similar results in elevation of serum levels of alpha-1 protease inhibitor and antichymotrypsin in the early phase of the disease.

While CRP showed significantly higher concentrations in patients who developed major complications, multiple organ dysfunction syndrome, or death in the further course of the disease, alpha- 1 protease inhibitor and antichymotrypsin levels changed slightly, but not significantly. Several authors studied alpha-1 protease inhibitor and trypsin-alpha-1 protease inhibitor complex in patients with pancreatitis, but only a few have studied the predictive value of alpha-1 protease inhibitor for the severity of pancreatitis. The results are controversial. Banks et al. ${ }^{[13]}$ found no significant difference in concentrations of alpha- 1 protease inhibitor between mild and severe groups. Ranson ${ }^{[18]}$ stressed its diagnostic value more than its prognostic power. Viedma et al. ${ }^{[19]}$ pointed out that the concentration of alpha-1 protease inhibitor increased during the pancreatic attack in both groups, and alpha-1 protease inhibitor levels in serum were reported to discriminate severe from mild cases, with significance. In the study of Hedstorm et al. ${ }^{[15]}$ about trypsin-alpha-1 protease inhibitor complex, the difference between mild and severe cases was significant.

This study showed no beneficial effect of alpha-1 protease inhibitor and antichymotrypsin in the prediction of severity. However, they are highly valuable as an early marker in patients with acute pancreatitis.
In conclusion, alpha-1 protease inhibitor and antichymotrypsin are rapidly produced variables in inflammation of the pancreas and have a faster response than CRP. For this reason, they may be diagnostic variables in patients with acute pancreatitis. Because neither of them is good at discrimination between mild and severe cases in the disease and measurement techniques are not suitable for clinical use, they should not be included in routine investigations. These results require further study in larger patient series including controls.

\section{REFERENCES}

1. Tulp N. Observationum medicarum, Editio Nova et Aucta. 2nd ed. Amsterdam, The Netherland; 1652:345. Book 4. Cited by Howard JM, Hess W. History of the pancreas. New York: Kluwer; 2002.

2. Elman R, Arneson N, Graham EA. Value of blood amylase estimations in the diagnosis of pancreatic disease: a clinical study. Arch Surg 1929;19:943-67.

3. Bradley EL 3rd. A clinically based classification system for acute pancreatitis. Summary of the International Symposium on Acute Pancreatitis, Atlanta, Ga, September 11 through 13, 1992. Arch Surg 1993;128:586-90.

4. Chen CC. Serum markers in the early assessment of severity of acute pancreatitis: which is the most useful? J Chin Med Assoc 2004;67:439-41.

5. Ohlsson K, Olsson AS. Purification and partial characterization of human pancreatic elastase. Hoppe Seylers Z Physiol Chem 1976;357:1153-61.

6. Adham NF, Dyce B, Haverback BJ. Trypsin-binding -2-macroglobulin in patients with acute pancreatitis. Gastroenterology 1972;62:365-72.

7. Uhl W, Büchler M, Malfertheiner P, Martini M, Beger HG. PMN-elastase in comparison with CRP, antiproteases, and $\mathrm{LDH}$ as indicators of necrosis in human acute pancreatitis. Pancreas 1991;6:253-9.

8. Heath DI, Wilson C, Gudgeon AM, Jehanli A, Shenkin A, Imrie CW. Trypsinogen activation peptides (TAP) concentrations in the peritoneal fluid of patients with acute pancreatitis and their relation to the presence of histologically confirmed pancreatic necrosis. Gut 1994;35:1311-5.

9. Rau B, Steinbach G, Gansauge F, Mayer JM, Grünert A, Beger HG. The potential role of procalcitonin and interleukin 8 in the prediction of infected necrosis in acute pancreatitis. Gut 1997;41:832-40.

10. Mayer J, Rau B, Grewe M, Schoenberg MH, Nevalainen TJ, Beger HG. Secretory phospholipase A2 in patients with infected pancreatic necroses in acute pancreatitis. Pancreas 1998; 17:272-7.

11. Gross V, Leser HG, Heinisch A, Schölmerich J. Inflammatory mediators and cytokines--new aspects of the pathophysiology and assessment of severity of acute pancreatitis? Hepatogastroenterology 1993;40:522-30.

12. McMahon MJ. Plasma markers of pancreatic necrosis. In: Bradley EL III editor. Acute pancreatitis: diagnosis and therapy. New York: Raven Press; 1994. p. 47-55.

13. Banks RE, Evans SW, Alexander D, Van Leuven F, Whicher JT, McMahon MJ. Alpha 2 macroglobulin state in acute pancreatitis. Raised values of alpha 2 macroglobulinprotease complexes in severe and mild attacks. Gut 
1991;32:430-4.

14. Goodman AJ, Bird NC, Johnson AG. Antiprotease capacity in acute pancreatitis. Br J Surg 1986;73:796-8.

15. Hedström J, Sainio V, Kemppainen E, Haapiainen R, Kivilaakso E, Schröder T, et al. Serum complex of trypsin 2 and alpha 1 antitrypsin as diagnostic and prognostic marker of acute pancreatitis: clinical study in consecutive patients. BMJ 1996;313:333-7.

16. McMahon MJ, Bowen M, Mayer AD, Cooper EH. Relation of alpha 2-macroglobulin and other antiproteases to the clini- cal features of acute pancreatitis. Am J Surg 1984;147:16470 .

17. Lasson A, Ohlsson K. Protease inhibitors in acute human pancreatitis. Correlation between biochemical changes and clinical course. Scand J Gastroenterol 1984;19:779-86.

18. Ranson JH. Diagnostic standards for acute pancreatitis. World J Surg 1997;21:136-42.

19. Viedma JA, Pérez-Mateo M, Agulló J, Domínguez JE, Carballo F. Inflammatory response in the early prediction of severity in human acute pancreatitis. Gut 1994;35:822-7. 